\title{
Producing (im)Possible Peoples: \\ Policy Discourse Analysis, In-State Resident Tuition and Undocumented Students in American Higher Education
}

\author{
Ryan Evely Gildersleeve \\ University of Denver \\ U. S. A. \\ Susana Hernandez \\ lowa State University \\ U. S. A.
}

This paper examines 12 states' statutes that extend in-state resident tuition for undocumented students, illustrating their ambiguities and contradictions as they produce the subject in these on-going policy debates. This study asks and answers the question: "How are students' identities produced in ISRT policy?" At stake in this question are the discursive opportunities made available for enabling and/or constraining higher education opportunity, particularly for undocumented students. Findings point to a contradictory set of identities simultaneously made possible and impossible for undocumented students pursuing American higher education.

\author{
Literature and Context \\ Poststructuralism \\ Method \\ Evidentiary Sources \\ Discursive Effects of ISRT Policy \\ Conclusions: Confronting Anti-Immigrant Discourse in ISRT Policy \\ Notes \\ References
}

In-State Resident Tuition (ISRT) policy for undocumented students has emerged within the frontlines of a national debate about immigration reform and educational opportunity. State statutes like Arizona's SB $1070^{1}$ and its subsequent popular response, both in favor and opposition, provide evidence for the hostile climate and the timeliness of such concerns. Additionally, as the U.S. Congress continually fails to address comprehensive immigration reform, understanding the consequences of state-based policy reform becomes even more pressing for educators and policy makers. Passions run high in this debate, and rhetoric is profuse. Cutting through the extant noise and fostering a deep understanding of how higher education, immigration, policy, and discourse are 
creating new and reifying old ideologies can be difficult but remains necessary if the education community wants to meet the challenge of a changing future.

Anti-immigrant discourse readily can be found in draconian legislation such as Arizona's SB1070 and Alabama's HB56. However, as responsible researchers and social justice advocates, we must look also in less obvious sites of cultural production. Indeed, poststructural thought and policy analysis point to a need for uncovering hidden meanings embedded within normative and subversive social texts (Allan, Iverson, \& Ropers-Huilman, 2010). Consequently, we must scrutinize policies and practices that are seemingly supportive of immigrant educational opportunity. For even in the most progressive of policies, we might find discourse that handily supports anti-immigrant ideologies. The effects of anti-immigrant discourse within seemingly pro-immigrant policy shape reality just as powerfully as more obviously anti-immigrant discourses.

In order to contribute to potential responsiveness from higher education, this study seeks to understand the underlying assumptions that drive ISRT policy, as enacted in its discourse. Drawing from Critical Discourse Analysis (Fairclough, 2006; Gee, 1999) and Policy Discourse Analysis (Allan, Iverson, \& Ropers-Huilman, 2010), this paper takes the text from 12 states' statutes that extend in-state resident tuition to undocumented students as primary evidentiary sources and examines them for ambiguities and contradictions as they construct the subject in these on-going debates. ${ }^{2}$

As such, this study asks and answers the question: "How are identities produced through ISRT policy?" At stake in this question are the discursive opportunities made available for enabling and/or constraining higher education opportunity, particularly for undocumented students.

\section{Literature and Context}

In the United States, it is estimated that there were approximately 11.9 million undocumented immigrants in 2008 (Pew Hispanic Center, 2008). Roughly $50,000-65,000$ undocumented students graduate from U.S. high schools each year (Olivérez, 2006). Undocumented students struggle for opportunity through complex webs of social, cultural, political, and policy contexts (López \& López, 2009; Perez, 2009; Suárez-Orozco, Suárez-Orozco, \& Todorova, 2008). They face discrimination across divisive lines of racialization, geography, social class, and, most pointedly, citizenship (Gildersleeve, 2010a; Olivas, 2011; Perez, 2010). Additionally, undocumented students often come from families that participate in labor contexts (e.g., migrant farmworking), which have been shown to be unsupportive of higher education opportunity (Gildersleeve, 2010b). Many undocumented immigrants' socio-economic status presents a pressing problem for students, similar to that of their documented counterparts: the ability to pay for higher education. 
However, unlike students with U.S. citizenship, undocumented students' access to financial aid is extremely limited. They are ineligible for federal aid, and most states and many private foundations restrict aid to students with legal residency or U.S. citizenship (Flores, 2010; Gildersleeve, Rumann, \& Mondragón, 2010; Olivas, 2011). Further, higher education costs can be exacerbated for undocumented students when states refuse to consider them residents for tuition purposes. Partly in response to this inequity, 14 states have approved policies that effectively extend in-state resident tuition benefits to undocumented students. Meanwhile, six states have adopted policies explicitly denying undocumented students tuition benefits. Still others remain policyambiguous, leaving individual institutions to determine their own practices.

An important federal statute influencing the state's ability to extend and/or restrict in-state resident tuition is the Illegal Immigration Reform \& Immigration Responsibility Act (IIRIRA) of 1996. The statute does not prohibit states from providing in-state resident tuition as long as qualified out-of-state U.S. citizen students are eligible for a similar benefit (Ruge \& Iza, 2005). The vagueness of the statute, however, has led to significant differences concerning the intent of the stipulation (Frum, 2007). While the intent behind this statute is interpreted in different and controversial ways, it is important to note that it does not preclude institutions from enrolling or admitting undocumented students (Ruge \& Iza, 2005).

It is imperative to recognize that the federal government generally is ascribed responsibility for concerns of immigration, while state governments generally are ascribed responsibility for concerns of education, including higher education. Individual institutions mediate opportunity at the organizational level by crafting policies and enacting practices that can constrain/enable student access and success. At stake, in this study, is a policy context that rests at a complicated nexus of these federal, state, and institutional responsibilities: instate resident tuition policy for undocumented students.

Research on ISRT policy has relied heavily on legal arguments about undocumented immigrants' rights to higher education as well as quantitative analyses of policy outcomes related to undocumented students. For example, Olivas (2004) provided syntheses of the legal landscape related to immigration and education, while Lipman (2006) argued for more equitable tuition policies based on legal-economic analyses that showed how undocumented immigrants are excessively taxed for higher education without benefitting from these private contributions to the public good. Meanwhile, scholars such as Flores (2007; 2010) and Kaushal (2008) have used enrollment, financial aid, and census data to demonstrate the overall benefit of ISRT policy for undocumented students, as well as the negligible impact of these policies on local higher education systems and economies. Dougherty, Nienhusser, and Vega (2010) examined the policy development of two ISRT policies. Their case studies of Arizona and Texas suggest that the politics of ISRT are beyond simple interests in either immigration or higher education, but rather might represent broader political interests. Some qualitative work has explored the affective consequences of ISRT policy in 
undocumented students' everyday lives, claiming ISRT policy can serve an empowering ethic that mobilizes undocumented students as activists (Morales, Herrera, \& Murry, 2009; Perez Huber \& Malagon, 2007).

Despite a growing literature related to undocumented students in higher education, and ISRT policy in particular, these policies have remained largely unexamined in terms of their discursive effects. This study begins to address this gap in the literature by providing critical and policy discourse analyses of enacted ISRT statutes. Such analyses can inform future policy-making that seeks to effect more systemic change in supporting undocumented students' access and opportunity. Understanding policy's underlying ideologies helps explain how policy produces meaning in the practical world. These are often hidden qualities to policy that cannot be found from traditional studies of policy development or evaluations of policy outcomes.

\section{Poststructuralism}

We root our analyses of the discursive effects of ISRT policy, in particular relation to the production of identities, on poststructural assumptions about discourse, power, and subjectivity. Core propositions within poststructural theories include the recognition that realities are subjective experiences and knowledges are historically-bound (Allan, 2010). As such, discourse, power, and identity are dynamic relations that produce realities and knowledges from which subjects (i.e., people) can take action.

\section{Discourse}

Poststructural theories assert that the life or meaning of any text relies upon its interplay with other texts, broader contexts, and the readers of those texts. This interplay and the action/meanings that carry forth from it can be understood as discourse. In short, discourse is the talk (or language) and action of a text. As Baxter (2003) writes, discourse is a "site for the construction and contestation of social meanings" (p. 6). As such, the meanings within texts are not lying in wait to be found, but rather meanings are constructed by the contingencies and pressures betwixt and between talk and action (i.e., discourse). Hence, discourse produces reality.

Understanding policy as discourse assumes that policy produces particular truths (albeit dynamic and unstable) and possible knowledges (albeit tentative and historically-bound). However, as policy discourse reflects and produces culture (Ball, 1994), the truths and knowledges produced through policy are acted upon as stable, unified, and self-evident. As Allan (2010) writes, "policy-as-discourse views policy as regulating social relations primarily through positive or productive means" (p. 25). That is, policy (as discourse) creates 
identities. As such, understanding the effects of policy requires us to deconstruct the identities that policy produces.

\section{Power}

Within poststructural theory, discourse and power are recursively interlocked (Allan, 2010). Indeed, power operates discursively and discourse relies on power to produce meanings in everyday lives. From a poststructural perspective, power is understood "as a productive force, rather than a primarily repressive one" (Allan, 2010, p. 16). Drawing largely from Foucault (1978; 1980), power is not a possession, but rather an exercise; power circulates by way of discourse between and across social relations. Power operates at local levels and change happens from a multitude of diverse power negotiations across (inter)related discourses.

Importantly, power and knowledge cannot be separated and are interdependent with discourse. Foucault (1978) instructs: "it is in discourse that power and knowledge are joined together" (p. 100). Power/knowledge then is negotiations across complex discourses that lead to an understanding of reality. Hence, truth, in poststructural thinking, is "an effect of power/knowledge operating through discourse" (Allan, 2010, p. 17). Power disperses as certain ways of knowing and being in the world are made possible.

\section{Identity and Subjectivity}

Discourse produces the self. As Luke (1995) put forward, we learn "to recognize, represent, and 'be,' for instance a 'rapper,' a 'learning disable,' a 'loyal American"' (p. 114) through discourse. These identities are made available for the self to adhere to as well as for others to affix onto individual and collective bodies via the subject positions made possible by the dynamic interplay of discourses. These struggles to make sense of, contest, and embody such subject positions illustrate the interdependent relationship of discourse and power (Wheedon, 1997). In this sense, identity is a power struggle.

In poststructuralist thought, subjectivity-the space(s) wherein the self is made known-is a constant site of struggle, crafted and shaped by the conflicting subject positions made available from various discursive fields. In opposition to humanist thought, there is no such thing as a unified self or stable identity. Rather, identities are made plausible as tentative, contested, and conflicted subject positions are produced through discourse. Applied to this study, we seek to understand (and disrupt) how power/knowledge circulates through ISRT policy discourse, forming possible subjects (and, as will be shown, objects) by the ways students are constructed. We recognize that pre-empting these subject positions with the identifier of "student" creates a tension within our framework. We view 
this tension as productive, however, in that we seek to understand the discursive effects through ISRT policy that contest, conflict, and re-shape possible "student" identities.

\section{Method}

Critical discourse analysis (CDA) is a methodology that assumes human realities are made possible through talk and action (Fairclough, 2006). We cannot come to understand a reality - conceptualize and intellectualize it without first being able to imagine it. As our imaginations are bound by language (albeit in a recursive relationship), discourse is assumed to be an interlocutor to reality. Different concepts of the world become discursively available for use through our talk and action-the text of our everyday lives. These are processes laden with power and ideological formation. As such, critical discourse analysis seeks to understand the construction of our available understandings of the world.

Policy discourse analysis (PDA) draws from CDA but focuses on the talk and action within policy: the text of policy, its meanings, and its discourse (Allan, Iverson, \& Ropers-Huilman, 2010). Of interest in PDA are the ambiguities and contradictions within and across policy discourses. These ambiguities and contradictions are assumed to be the lair for material formations of oppression and/or opportunity (or hope). These spaces are fissures within and across policy discourses that might afford possibility for change.

CDA and PDA are appropriate methods of analysis to investigate the construction of the subject in ISRT policy. Institutions act as a result of policy. This study interrogates the 12 legislative statutes that extend ISRT benefits to undocumented students. Through CDA, particular attention will be paid to the language that ISRT statutes use in order to form new understandings of students from the interplay between the text and its meanings (discourse). We loosely follow a linguistic model of CDA (Fairclough, 2006; Rogers, 2004), first establishing the text itself, then interpreting the text institutionally-that is, how the language of the text is institutionalized within the statutes themselves. Finally, we provide an explanatory interpretation of the identities constructed by and through the language choices of ISRT statutes.

PDA will help reveal further the fissures within ISRT policy, illustrating how ambiguities and contradictions afford spaces to constrain and/or enable opportunity for undocumented students. These fissures can also be home to potential unintended consequences of ISRT policy, thus again reshaping the available subject positions for undocumented students in their struggle for educational opportunity. We draw liberally from the poststructural method of deconstruction, which tries to draw attention to the plurality of meanings and the multiple intersections of discourse(s) that make these meanings possible (Wheedon, 1997). We merge our deconstructive work with the poststructural 
method of genealogy, grounded in Foucaultian assumptions of power/knowledge and seeking to examine how discourse shapes social practice, making certain ways of being plausible (Ramazanoğlu, 1993).

Ours is an inherently hybrid methodology (Allan, 2010), appropriating complementary methods to achieve a complex and anti-hegemonic goal: understanding the instantiation of anti-immigrant discourse in the ISRT policy regime. By focusing on the text of ISRT statutes, as instantiations of the ISRT policy regime, our analyses will show the discursive junctures wherein policy ideologically and politically mediates the reconstruction of identities in higher education, effectively producing and delineating the possibilities for being a person within the struggle for undocumented educational opportunity.

\section{Evidentiary Sources ${ }^{3}$}

This study uses the text of 12 states' legislative statutes that operate as extending ISRT policy. These 12 states have all enacted ISRT policies within the last 10 years, with Texas being the first in 2001 and Connecticut being the latest in 2011. While the implementation of ISRT policy varies across states and institutions, we choose to focus on the actual language of state-based ISRT legislative statutes to determine how identities are produced within ISRT policy.

We treat these 12 legislative statutes as a dynamic policy discourse in and of itself, albeit an unstable and tentative discourse that is subject to political will and whim. In this sense, we analyze these statutes as instantiations of what Foucault might call a "regime of truth" (1972). Cumulatively, these statutes effectively establish a certain way for the nation to understand and make sense of immigration and educational opportunity. Our aim in this article is to deconstruct how this regime of truth makes certain subject positions possible and, therefore, creates opportunities for certain identities to emerge.

Table 1: State-based in-state resident tuition statutes

\begin{tabular}{|c|c|c|}
\hline State & Statute & Year \\
\hline Texas & HB 1403 & 2001 \\
\hline California & AB 540 & 2001 \\
\hline New York & SB 7784 & 2002 \\
\hline Utah & HB 144 & 2002 \\
\hline
\end{tabular}




\begin{tabular}{|c|c|c|}
\hline Washington & HB 1079 & 2003 \\
\hline Oklahoma & SB 596 & 2003 \\
\hline Illinois & HB 60 & 2003 \\
\hline Kansas & HB 2145 & 2003 \\
\hline Nebraska & LB 239 & 2005 \\
\hline New Mexico & SB 582 & 2005 \\
\hline Wisconsin & AB 75 & 2009 \\
\hline Connecticut & H6390 & 2011 \\
\hline
\end{tabular}

\section{Discursive Effects of ISRT Policy}

What follows are the findings from our analysis of ISRT policy discourse. We divide these findings into two primary sections, organized by our orienting question around the discursive identities of undocumented students at stake in ISRT policy: 1) critical analyses of how the subject is constructed, and 2) poststructural analyses of how the subject is produced. Although interrelated, we choose to present the discursive effects produced by ISRT policy in these two broad categories for a basic level of clarity. We first present a critical rendering of the constructed meanings about the human subjects explicitly named in ISRT policy. We then provide a poststructural deconstruction of ISRT policy, unmasking discourses that illustrate identities produced through the action of the policy texts, in context, of undocumented students' sociopolitical locations, participation struggles, and legal/policy conditions. In a later section, we relate these findings - the discursive effects of ISRT policy-to plausible material consequences from which social action can be taken.

\section{Constructions of the Subject: Critical Renderings}

A brief textual overview of ISRT policy. Despite their political controversy, state policies that extend in-state resident tuition benefits provide a remarkably stable discourse of educational opportunity in that there is very little deviation between their core components. Each uses nearly identical 
requirements for students to qualify for in-state resident tuition benefits: graduate from an in-state high school, reside in the state for at least three years, have good moral character, and if not a citizen of the United States, and have entered the United States before the age of 16 and sign an affidavit that they legally reside in the United States or promise to seek legal authorization/citizenship should they become eligible. These core requirements are exactly the same across all 12 policies, yet these requirements do little to declare the policies' target populations.

Specific to the construction of the target subject in these policies, we found a total of five different single-subject nouns used. These nouns were (in alphabetical order): alien, individual, minor, person, and student. With the exception of the term "alien," which some scholars have already noted as culturally incendiary and/or offensive in popular discourse (see for example, Perez Huber, 2009), the rest of these terms are seemingly benign as signifiers of human subjects. However, policy subjects are not wholly constructed from simple nouns. Rather, these nouns become embedded in the broader text of the policy, or the policy's institutional context (Fairclough, 2006). The institutional context of ISRT policy constructs its policy target subjects in qualified ways and means. Put simply, more words are needed to clearly identify the targets of these policies. More words mean more context. More context means more discursive action.

Target subjects in the institutional context of ISRT policy: The qualified subject. When the policies actually put new law into effect, that is, the sections of policy texts that do the changing, broader definitions of aliens, individuals, minors, persons, and students are drawn. For example, when explaining who the in-state resident tuition benefit will be extended to through the passage of Washington's HB 1079 (2003), the policy text qualifies the person as "a person who is not a citizen of the United States of America." The simple subject-person—becomes more complex and more specific. Inclusion/exclusion criteria are generated. In this case, Washington is not talking about any or all persons. Rather, only persons without U.S. citizenship. The text qualifies the potential identity construct of "person," clarifying the target of the policy. The single-subject nouns serve as building blocks for these qualified subjects.

New York's SB 7784 (2002) qualifies their subject as "a student without lawful immigration status." While Oklahoma's SB 596 (2003) used a broader and more sweeping subject identity, stating, "high school counselors shall inform immigrant students that they should apply for legal status as soon as possible." In each of these cases, the target of the policy (i.e., undocumented students), requires a qualification-these students do not stand on their own as students, but rather must be qualified by policy in ways that designate them as separate from the normative identity of 'student.'

Explaining the target subjects of ISRT policy: The alien student. Just as the single-subject nouns served as the building blocks to construct qualified 
subject identities, these in turn afford the opportunity for new discursive identities to come into being. A new discursive identity is one that emerges from the constituent parts of existing discourse. It provides an explanatory rendering of the identities constructed by the institutional context, in relation to the broader social contexts of the policy. In the case of ISRT policy, we found two examples of new discursive identities: "the alien student" (CA AB540, 2001) and "the student alien" (NE LB239, 2005). Prior to ISRT policy, such signifiers of human bodies were not available in political or popular discourse. These new identities certainly were not in the everyday speech of educators. Rather, they only become available via the text of these policies. As such, ISRT policy has effectively created a new type of person-a new identity-to use as its target subject.

These critical renderings of the policy subject, those whom the policy targets its action toward, afford a deeper understanding of how ISRT policy is situated in relation to the possible subjects (i.e., people) it can affect. By declaring policies to focus on individuals, minors, persons, or students, these policies make explicit claims to effecting change in social relations, particularly in the realm of education. By qualifying these subject signifiers, ISRT policy then sets up exclusion/inclusion criteria by naming the qualities at stake in different students' lives that would make them subject to this policy. The qualified subjects are set apart from normative subjects. An undocumented student, discussed as an "individual who is not a citizen or a permanent resident of the United States" (IL HB 60, 2003), is not a normal student, but rather an exceptional student who will benefit from this policy that names her/him an exception.

Critical renderings can only show part of the discursive effects of ISRT policy in relation to the identities available for undocumented students. Critical renderings are limited to the questions posed by the policy itself. They can offer us clarity into how the policy discourse puts itself forward and in so doing puts forward the possible new subject position of Nebraska's "student alien." However, ISRT policy reaches farther into the modes of subjectivity for undocumented students. Not only are new identities constructed within the policy texts, but new subject positions are also produced through these policies.

\section{Productions of the subject: Deconstructing "The Alien Student."} Taking a poststructural turn in our analysis, we seek to examine "The Alien Student," as it is produced through the ISRT policy regime. Effectively, we need to understand how The Alien Student makes different subject positions possible-subject positions that get reified as identities, which can then be ascribed to and action taken from in the minds of policy-makers, educators, and students. Through poststructural renderings, we can take note of the absent markers of the subject and the tensions between concepts that might be oversimplified as binaries, like good or bad. Our deconstruction/genealogy of The Alien Student seeks to dislocate the ideologies that drive the logics of this new discursive identity. By dislocating these ideologies, we can expose plausible material consequences that might otherwise become naturalized through the 
logics operating within the policy texts. We can point out the significance of antiimmigrant discourse that exists even within "pro-immigrant" legislation.

Humanizing/dehumanizing discourse. In effect, many of the singlesubject nouns and qualified subject signifiers used in ISRT policy can be understood as efforts to humanize policy. By this we mean that they extend definitions of who a person is or what makes somebody considered a student. At moments in some ISRT statutes, these language choices afford ISRT policy a human face. Avoiding federal immigration discourse, such as "resident alien" or "alien minor" as found in texts like the Illegal Immigration Reform and Immigrant Responsibility Act, effectively centers the policy on the education of a real person, or a real group, like undocumented students. Ostensibly, this might be the discourse expected from a policy that purportedly extends greater educational opportunity to a historically marginalized community.

Simultaneously alongside, betwixt, and even between moments of humanizing language, ISRT statutes are rife with dehumanizing language. Those same building blocks, in different and similar arrangement, effectively turn undocumented students from subjects into objects. The most obvious offenders here are the uses of "alien" to refer to undocumented students. Perez Huber (2009) argued that "alien" produces a human subject that is foreign to humanity, and simply is an affront on the livelihood and dynamic identities practiced by undocumented students seeking college opportunities. This dynamic has already been shown in the analyses of testimonios done by Perez Huber (2009) that demonstrated dehumanizing consequences from nativist discourse stemming from language such as "alien." But, the logic of dehumanization rests in less suspect subject constructions as well.

Some of the very same qualified subject identities that give a human face to the policy simultaneously operate from dehumanizing language, effectively stripping undocumented students of agency. For example, when Utah, New York, and Oklahoma each talk about a "student without lawful immigration status," not only do these policies afford a human face to their changes in benefits, they also exclude a class of students from the normative understanding of what a student can be. "Student" in these configurations would not need to be qualified. By qualifying "student" with the lack of "lawful immigration status," the text produces a new identity that is less-than a "student" who does not require the qualification. The qualified identities objectify undocumented students by making them the object of policy rather than the subject of policy. Even though they use different subject nouns, they effectively contribute to the construction of The Alien Student by targeting undocumented students through such qualified language.

Discourse of legitimacy. The Alien Student must be understood in relation to other actions of ISRT policy texts. We have argued elsewhere (Gildersleeve \& Hernandez, 2010) that ISRT policy produces a crisis of legitimacy in the battle over legislative autonomy between the states and the 
federal government. Salsbury's (2004) legal analysis of ISRT statutes lends support here. She concluded that ISRTs take one of two types of legal arguments: they either define residency as inclusive of undocumented immigrant students, or they describe exceptions to residency policy. Salsbury argues that the former is perhaps more effective in withstanding scrutiny under federal regulations. We identify three discursive actions that produce a legitimacy crisis discourse that can be found from deconstructing mechanisms/technologies within the ISRT statutes themselves. Most ISRT policies include a clause that explicitly directs specific entities as responsible for implementing the policy. In California's AB540, this responsibility lies with the California State University Board of Directors, the University of California's Board of Regents, and the California Community Colleges' local district offices. Effectively, these directives reinforce the legitimacy of the policy as it directs local—not federal-officials to put the policy into practice.

Yet, simultaneously, nearly every ISRT statute draws on federal immigration legislation discourse to make its point that these are not policies under federal responsibility. For example, Utah's HB144 states, "If allowed under federal law," and California's AB540 goes so far as to declare, "This act ... does not confer postsecondary education benefits on the basis of residence within the meaning of Section 1623 of Title 8 of the United States Code." Clearly, these statements are intended to separate the state action from any federal action, but in doing so they generate a discourse that allows the contestation of legitimacy over the social opportunities of undocumented students.

Each ISRT requires that students fill out an affidavit swearing to their legal status and/or promising to seek legal status if available. We have previously argued the affidavit supports this legitimacy crisis discourse (Gildersleeve \& Hernandez, 2010). The affidavit, having no educational value whatsoever, essentially acknowledges that states and institutions recognize a federal interest is at stake (i.e., immigration), but they wish to obfuscate the need for federal intrusion on their campuses by gathering a good-faith promise from students that they will become compliant with federal regulations. When the affidavit, the allusion to federal immigration legislation, and the directives of authority are examined in context of each other, the crisis of legitimacy becomes clearer. The mechanisms of the affidavit and the authorizing directive serve to obscure the federal immigration interests at stake in the policy, supposedly securing the legitimate right of the state to enact such education legislation. Ironically, these very mechanisms simultaneously call the legitimacy of this right into question by invoking the federal discourses of immigration, effectively acknowledging that the federal government has a stake in the consequences of the policy. Hence, the policy engages a legitimacy crisis around the right to legislate opportunity for undocumented students.

Politicizing immigrant bodies. The legitimacy discourse that produces a crisis over who has the right and responsibility to manage and/or construct opportunity for undocumented students consequently politicizes the 
undocumented immigrant body. As seen in the conflict between the ways that ISRT policy constructs the problem as one of higher education, residency, tuition, and perhaps equity, and the ways that ISRT policy produces a problem as the struggle for legitimacy in regulating these concerns, immigrant bodies become the theater whereupon states and the federal government battle for control over the shape, conditioning, and morality of American democracy. Higher education, as a democratic and social institution, is implicated deeply in this battle, yet the bodies of immigrant families and their social opportunity are used as characters, scenery, and plot in the theater of federal and state political entanglement.

The legitimacy discourse effectively makes The Alien Student a position of contestation, yet removes the actual student from engaging within that contestation. Rather, The Alien Student is reduced to an object of ISRT policy. As the objects of policy, undocumented students become the battlefield in which state and federal discourse collide. Extending ISRT policy is politicizing immigrant bodies through the construction and production of The Alien Student. The subject positions enabled through ISRT policy emerge from the nexus of state and federal discourses operating within humanizing/dehumanizing frames to describe the policies' targets. This nexus is a contestation of subjects becoming objects of policy and consequently politicizing immigrant bodies.

Empowerment of undocumented subjects. The politicization of undocumented immigrant bodies need not exclusively marginalize students. One material action of extending ISRT statutes is to extend tuition benefits to undocumented students, arguably leveling one mediator of educational opportunity. In light of this, The Alien Student could potentially be appropriated through a progressive politic and claim liberatory space in a new identity. As much as the policy might "other" or objectify undocumented students, it also provides new language from which these very students can produce new identities: "I am AB540!," referring to California's ISRT, has become a battle-cry of some student activists and grassroots coalitions in California engaging in social critique and social change for more equitable education policy (Abrego, 2008). The very target of objectification is afforded discursive ability to produce an empowering subjective identity.

Herein lies another contradiction of (anti-) immigrant discourses circulating through ISRT policy. As far as they produce possibilities for the objectification and politicization of immigrant bodies, ISRT policy discourses also make available an opportunity to "answer the call" (Butler, 1990) and confront the dehumanizing, draconian, vitriolic discourses that pervade popular rhetoric today. Yet, should undocumented students and their advocates choose to do so, they must precariously engage and contend with discourses that might more readily serve to undermine their social justice, democratic, and liberatory imperatives. As poststructural notions of subjectivity and subject locations inform, identities are fragile, unstable, and dynamic. They slip easily in and out of various discursive formations, contingent on the accessibility and availability of intersecting discourses across contexts. 


\section{Conclusions: Confronting Anti-Immigrant Discourse in ISRT Policy}

The constructs within ISRT discourse are conduits of power exercised to shape the body politic of undocumented students and discipline the potential emergent educational pathways for undocumented students. Those who inform, produce, and implement policy documents that attempt to extend educational opportunity for undocumented students can be more informed and critical of the ways in which ISRT policies are discursively constituted. Uncovering the hidden meanings embedded within extending ISRTs reveals the pervasive antiimmigrant discourse that seemingly supports educational opportunity for undocumented students, yet simultaneously endangers such opportunity. The pervasiveness of anti-immigrant discourse suggests an acute imperative for popular pedagogies (Freire, 1970) that resist and counter such hegemonic notions of immigrants. Such public pedagogy could foster a groundswell of critique enabling new discursive opportunities for anti-hegemonic and more progressive ideals to become plausible.

Through a public pedagogy, postsecondary educators can seek to humanize the dehumanizing discourse of policy in its local instantiations. Administrators can translate statewide ISRT statutes into transformative local policies that resist perpetuating the objectification of students. Institutional policy documents can be drawn and disseminated that simply explain all of the ways that various students can qualify for in-state tuition benefits. However, transforming dehumanizing state-level policy into more humanizing institutional policy does little to address the systemic and social pervasiveness of the antiimmigrant discourse in ISRT policy. It might effectively silence or ignore the dehumanization and politicization of immigrant bodies, but it does little to dismantle it.

A public pedagogy linking anti-immigrant discourses, like those found in ISRT policy, to broader discourses circulating through education and immigration might prove more effective. For example, Kuntz, Gildersleeve, and Pasque (2011) identified ways that federal initiatives discursively render postsecondary education as primarily an individual and economic benefit. Within such a frame, it is easy to accept and perpetuate the anti-immigrant discourse found within ISRT, as the benefits of postsecondary education become scarce commodities to be coveted and protected. Whereas a more egalitarian discourse-one that conceives of higher education as a social benefit-could afford more pluralistic and humanizing avenues to expand opportunity. Educators, policy-makers, and researchers can work to connect progressive discourses in broader social movements, rather than fall trap to challenging anti-immigrant discourses within more narrowly defined fields and institutions. Teach-ins, professional development programs, and mentoring activities all provide opportunities for such discursive contestation. 
Our analysis suggests a key site of intervention already taking form for confronting anti-immigrant discourse-the new discursive productions of undocumented students themselves. Working with undocumented student groups to produce new connections across discourses seems like an obvious strategy, and indeed some evidence already exists to support such initiative. Examples of alternative graduation ceremonies (see Gildersleeve, 2011), underground publications (see Madera et al., 2008), and informal networks of support focused on constituting universities as sites of contest and change have emerged across campuses. Policy-makers, administrators, and educators can look to these student-initiated organizations and activities for leadership. Collaborating with undocumented student groups in institutional policy-making, public discourse programs, and professional developments seems a logical firststep in making connections and identifying opportunities for humanizing antiimmigrant discourse.

The power of language to shape and inform new identity constructs raises new junctures for critique through future research. The examination of other proimmigrant policy such as the federal DREAM Act can raise new understandings of the ubiquitous nature of anti-immigrant ideology. The discursive effects of ISRT policy and the politicizing of immigrant bodies can provide new explorations of the lived experiences of "The Alien Student." How these new identities inform the material action of students' lives should be explored further. Potential future research questions might include: "How does the marking of immigrant bodies shape the daily experience of students on college campuses?" and "What are the material structures that mediate how new identities can be practiced?"

Our critical and policy discourse analyses revealed that even policy generally considered to be pro-immigrant, and indeed providing a benefit to immigrant populations (i.e., undocumented students), can uphold anti-immigrant ideology. Through "The Alien Student," ISRT policy enables an objectification of undocumented students, positioning students' bodies as a battleground for power struggles between the states and the federal government. While this battle plays out, real people lose opportunity, and the struggle for equity in immigration and education perpetuates the discursive field it might very well seek to dismantle. Yet, all hope is not lost, as this very same field of discourse can be influenced and rendered anew through liberatory intersections, like the empowerment of immigrant youth that might prove productive in such a struggle.

\section{Notes}

1. Arizona SB1070 is an anti-immigrant measure passed by the Arizona legislature that, among other things, restricts in-state resident tuition benefits from undocumented students. Many parts of the controversial law remain entangled in federal courts. Georgia and Alabama have subsequently passed similar laws. 
2. We recognize that we are ourselves discursively producing identities by deploying the term "undocumented student" in order to refer to the group of people most at stake in our analysis. We believe this tension is inherent in work such as this. We also recognize the political nature of language when working with immigrant youth. We appropriate the linguistic analysis of López and López (2010) in choosing this term, and we refer readers to their text for a fuller explanation of the choice.

3. Oklahoma and Wisconsin each passed legislation that extended in-state resident tuition benefits to undocumented students, but subsequently overturned this legislation in 2009 and 2011 respectively. We include the original extending legislative statutes from Oklahoma and Wisconsin in our analysis. Rhode Island's Board of Governors for Higher Education adopted a state-wide institutional policy that extends in-state resident tuition policy benefits to undocumented students. However, we do not include Rhode Island's policy because it is not a legislative statute like the rest of our evidentiary sources. Maryland has an extending in-state resident tuition policy but restricts the benefits to community college students. As such, we have not included Maryland's policy in our analysis.

\section{References}

Abrego, L. (2008). Legitimacy, social identity, and the mobilization of law: The effects of Assembly Bill 540 on undocumented students in California. Law \& Social Inquiry, 33(3), 709-734.

Allan, E. J. (2010). Feminist poststructuralism meets policy analysis: An overview. In E. J. Allan, S. V. D. Iverson, \& Ropers-Huilman (Eds.), Reconstructing policy in higher education: Feminist postructural perspectives (pp. 11-36). New York: Routledge.

Allan, E. J., Iverson, S. V., \& Ropers-Huilman, R. (2010). Introduction. In E. J. Allan, S. V. D. Iverson, \& Ropers-Huilman (Eds.), Reconstructing policy in higher education: Feminist postructural perspectives (pp. 1-10). New York: Routledge.

Ball, S. J. (1994). Education reform: A critical and post-structural approach. Buckingham: Open University Press.

Baxter, J. (2003). Positioning gender in discourse: A feminist methodology. New York: Palgrave-Macmillan.

Butler, J. (1990). Gender trouble. New York, Ny: Routledge.

Dougherty, K. J., Kenny Nienhusser, H., Vega, B.E. (2010). Undocumented immigrants and state higher education policy: The politics of in-state tuition eligibility in Texas and Arizona. The Review of Higher Education, 34, 123-173. 
Fairclough, N. (2006). Discourse and social change. Cambridge, UK: Polity Press.

Flores, S. M. (2007). The effect of in-state resident tuition policies on undocumented Latino students in Texas and the United States (Unpublished doctoral dissertation). Harvard University, Cambridge, MA.

Flores, S. M. (2010). State Dream Acts: The effect of in-state resident tuition policies and undocumented Latino students. The Review of Higher Education, 33(2), 239-283.

Foucault, M. (1972). The archeology of knowledge and the discourse on language. New York, NY: Pantheon Books.

Foucault, M. (1978). The history of sexuality: Volume I: An introduction. (R. Hurley, Trans.). New York, NY: Vintage Books.

Foucault, M. (1980). Power/knowledge: Selected interviews and writings, 19721977. Brighton, UK: Harvester Press.

Freire, P. (1970). Pedagogy of the oppressed. New York, NY: Seabury Press.

Frum, J. L. (2007). Postsecondary educational access for undocumented students: Opportunities and constraints. American Academic, 3, 81-107.

Gee, J. P. (1999). An introduction to discourse analysis. New York, NY: Routledge.

Gildersleeve, R. E. (2010a). Access between and beyond borders. Journal of College Admission, 206, 3-10.

Gildersleeve, R. E. (2010b). Fracturing opportunity: Mexican migrant students and college-going literacy. New York, NY: Peter Lang.

Gildersleeve, R. E. (2011). A call for generative hope in the struggle for undocumented students' educational equity. $21^{\text {st }}$ Century Scholar. Retrieved from www.21stcenturyscholar.org

Gildersleeve, R. E., \& Hernandez, S. (2010). Undocumented immigrant students in American higher education policy and discourse [Monograph]. Retrieved from http://www.law.uh.edu/ihelg/series.html

Gildersleeve, R.E., Rumann, C., \& Mondragón, R. (2010). Serving undocumented students: Current law and policy. In Price, J. (Ed.) New directions for student affairs: Understanding and supporting undocumented students (pp. 5-18). San Francisco, CA: Jossey-Bass.

Kaushal, N. (2008). In-state tuition for the undocumented: Education effects on Mexican young adults. Journal of Policy and Management, 27(4), 771792.

Kuntz, A. K., Gildersleeve, R. E., \& Pasque, P. (2011). Obama's American graduation initiative: Race, conservative modernization, and a logic of abstraction. Peabody Journal of Education 86(5), 488-505. 
Lipman, F. J. (2006). The taxation of undocumented immigrants: Separate, unequal and without representation. Harvard Latino Law Review, 9, 1-58.

López, M. P., \& López, G. R. (2009). Persistent inequality: Contemporary realities in the education of undocumented Latina/o students. New York, NY: Routledge.

Luke, A. (1995). Text and discourse in education: An introduction to critical discourse analysis. In M. W. Apple (Ed.), Review of research in education, 21 (pp. 3-48). Washington, DC: American Educational Research Association.

Madera, G., Mathay, A. A., Najafi, A. M., Saldívar, H. H., Solis, S., Titong, A. J. M., Rivera-Salgado, G., Shadduck-Hernández, J., Wong, K., Frazier, R., \& Monroe, J. (2008). Undocumented undergrads: UCLA undocumented immigrant students speak out. Los Angeles, CA: UCLA Center for Labor Research and Education.

Morales, A., Herrera, S., \& Murry, K. (2009). Navigating the waves of social and political capriciousness: Inspiring perspectives from DREAM-eligible immigrant students, Journal of Hispanic Higher Education, 8(1), 1-18.

Olivas, M. A. (2004). IRRIRA, the DREAM Act, and undocumented college student residency. Journal of College \& University Law, 30, 435-464.

Olivas, M.A. (2011). No undocumented child left behind. New York, NY: New York University Press.

Olivérez, P. M. (2006). The college and financial aid guide for: AB540 Undocumented Immigrant Students. Los Angeles, CA: Center for Higher Education Policy Analysis, University of Southern California.

Perez, W. (2009). We are Americans. New York, NY: Stylus Press.

Perez, P. (2010). College choice process of Latino undocumented students: Implications for recruitment and retention. Journal of College Admission, 206, 21-25.

Perez Huber, L. (2009). Challenging racist nativist framing: Acknowledging the community cultural wealth of undocumented Chicana college students to reframe the immigration debate. Harvard Educational Review, 79(4), 704729.

Perez Huber, L., \& Malagon, M. C. (2007). Silenced struggles: The experiences of Latina and Latino undocumented students in California. Nevada Law Journal, 7(841), 841-861.

Pew Hispanic Center (2008). Trends in unauthorized immigration: Undocumented inflow now trails legal inflow. Washington, D.C.: Pew Research Center

Ramazanoğlu, C. (1993). Introduction. In C. Ramazanoğlu (Ed.), Up against Foucault: Explorations of some tensions between foucalt and feminism (pp. 1-25). New York, NY: Routledge. 
Rogers, R. (2004). An introduction to critical discourse analysis in education. In R. Rogers (Ed.), An introduction to critical discourse analysis in education (pp. 1-18). Mahwah, NJ: Lawrence Erlbaum Associates.

Ruge, T. R., \& Iza, A. D. (2005). Higher education for undocumented students: The case for open admission and in-state tuition rates for students without lawful immigration status. Indiana International and Comparative Law Review, 15(257), 1-22.

Salsbury, J. (2004). Evading "residence": Undocumented students, higher education, and the states. American University Law Review, 53, 459-490.

Suárez-Orozco, C., Suárez-Orozco, M., \& Todorova, I. (2008). Learning a new land: Immigrant students in American society. Cambridge, MA: Harvard University Press.

Wheedon, C. (1997). Feminist practice and poststructural theory. Malden, MA: Blackwell. 